\title{
Evaluating the importance of fluid- melt interaction to rare-metal mineralization
}

\author{
ROBERT L. LINNEN ${ }^{1}$, ALYSHA G. MCNEIL ${ }^{1}$ AND ROBERTA \\ L. FLEMMING ${ }^{1}$ \\ ${ }^{1}$ Department of Earth Sciences, University of Western \\ Ontario,rlinnen@uwo.ca
}

The term 'stewed in its own juices' has been applied to granites and pegmatites by numerous authors and may be relevant to $\mathrm{Nb}-\mathrm{Ta}$ mineralization, which is commonly associated with complex mineralogy and metasomatism [1]. However, few experimental studies have investigated fluidmelt interactions in rare-metal bearing granitic systems at magmatic conditions. $\mathrm{Nb}$-Ta minerals commonly are composed of high field strength elements (HFSE: $\mathrm{Nb}$ and $\mathrm{Ta}$ ), which have very low fluid-melt partition coefficients, and unior bi-valent cations, which have much higher coefficients. The solubilities of different $\mathrm{Nb}-\mathrm{Ta}$ minerals, e.g., columbite, tantalite, pyrochlore, microlite, wodginite are strongly dependent on the concentrations of bivalent cations ( $\mathrm{Fe}, \mathrm{Mn}$, $\mathrm{Ca}$ [2] and it was postulated that metasomatic rare-metal mineralization may result from melts with high concentrations of HFSE with bivalent cations that are transported by fluids.

In order to test whether such interaction is viable, experiments were conducted where $\mathrm{Nb}$ - and $\mathrm{Ta}$-rich melts interacted with Mn-rich fluids. Glasses were synthesized to represent a highly fractionated melt composition with a molar $\mathrm{Al} /(\mathrm{Na}+\mathrm{K})$ of $\sim 1.0$ and $\sim 1.0 \mathrm{wt} \% \mathrm{Li}_{2} \mathrm{O}, 2.4 \mathrm{wt} \% \mathrm{~B}_{2} \mathrm{O}_{3}$ and $0.9 \mathrm{wt} \% \mathrm{~F}$, and $5000 \mathrm{ppm} \mathrm{Nb}$ or Ta. The fluid was synthesized to reflect a low salinity magmatic composition with $3.6 \mathrm{wt} \%$ $\mathrm{NaCl}$ and $2.2 \mathrm{wt} \% \mathrm{KCl}$, as well as $2.3 \mathrm{wt} \% \mathrm{MnCl}_{2}$. The main conclusions are: 1$)$ the solubility product $[\mathrm{MnO}] *\left[\mathrm{Nb}_{2} \mathrm{O}_{5}\right]$ is reproducible, whether columbite-(Mn) saturation of the melt was attained by dissolution, crystallization or fluid-melt interaction. This indicates that the solubility products obtained by fluid-melt interaction are equilibrium values, which opens a new experimental strategy for examining the stability and solubility of HFSE minerals; 2) Lithiophilite [LiMnPO ${ }_{4}$ ] also crystallized in some experiments, indicating that fluid-melt interaction may also be important in controlling phosphate crystallization at some deposits; 3) The interaction of a fluid rich in soluble elements $(\mathrm{Fe}, \mathrm{Mn}, \mathrm{Ca}$ and $\mathrm{Sn}$ ) with a melt enriched in HFSE (Nb, Ta, P) is consistent with the textures observed at many rare-metal granites and pegmatites. [1] Van Lichtervelde et al. 2007 Econ. Geol. 102, 257-276. [2] McNeil et al. Lithos 352-353. 